\title{
外乱オブザーバを応用した高さが未知な段差を昇降可能な車椅子の開発
}

竹森 史暁 ${ }^{* 1}$

\section{Development of wheelchair that can acsend and descend unknown height step by using disturbance observer}

\author{
Fumiaki TAKEMORI ${ }^{* 1}$ \\ ${ }^{* 1}$ Tottori University, Graduate School of Engineering \\ 4-101 Koyamacho-Minami, Tottori 680-8552, Japan
}

Received: 20 October 2020; Revised: 25 January 2021; Accepted: 15 February 2021

\begin{abstract}
Although wheelchair is useful as hardware for moving purposes such as the elderly and disability person, it is not suitable for driving in environments other than flat ground such as steps and ditches, and so there is a problem that the range of activities is limited. In this paper, we propose an add-on type step elevating mechanism and its control method that realizes step movement without the need for human visual inspection or intervention of operation in wheelchair elevating operation. The basic configuration of the mechanism consists of two arm rotation mechanisms whose drive source is a linear actuator and auxiliary drive wheels. By cooperative controlling these devices, it is possible to move the step by the chair occupant alone and while maintaining the horizontal posture. Applying a disturbance observer, this paper suggests a method that can estimate the step height without the need for a dedicated sensor even when a wheelchair user encounters the step for the first time. As a result of implementing this step detection method, it is shown that a step of up to 175 $\mathrm{mm}$ can be detected without relying on human eyes and its height can be estimated within the tolerance without using a dedicated sensor. In addition, it was confirmed that wheelchair with an adult man actually boarded can ascend and descend step height of $140 \mathrm{~mm}$, as a result of implementing an arm movement model that realizes step up and down while maintaining the posture of the wheelchair body horizontally for the arm mechanism after touchdown.
\end{abstract}

Keywords : Wheelchair, Disturbance observer, Traveling stairs by personal vehicle, Height estimation without sensor, Welfare technology

\section{1. 緒言}

2013 年に施工された交通政策基本法第 17 条（国土交通省，交通政策基本法，2019）では，高齢者・障害者・妊 産婦・乳幼児を同伴する者等の円滑な移動の促進のための自動車・鉄道・船・航空機・旅客施設・道路・駐車場の バリアフリー化が促進されている。このため，車椅子利用者にとってアクセシビリティが高い環境が整うことは， 他者の助力に頼る機会が減ることに繋がり QOL の向上にも期待できる．また近年における高齢者の自動車運転免 許証返納の推奨による自動車に替わる移動手段として, 電動車椅子のほかシニアカーのニーズが高まる可能性が ある。このような社会的背景から，電動車いす安全普及協会の統計によ机ば，電動車椅子の年間出荷台数は 2016 年以降毎年 2 万台を超えており一定の需要があることが報告されている（電動車いす安全普及協会，2019）.

車椅子は高齢者や障害者などの移動目的のハードウェアとて有用であるが，段差や溝など平地以外の環境での 走行には向かず，活動範囲が制限されてしまう問題がある。実際，近年の ITC の普及によりバリアフリーマップ

No.20-00376 [DOI:10.1299/transjsme.20-00376], J-STAGE Advance Publication date : 25 February, 2021

$*_{1}$ 正員，鳥取大学大学院工学研究科（T 680-8552 鳥取県鳥取市湖山町南 4-101)

E-mail of corresponding author: take@tottori-u.ac.jp 
が提供されてはいるが，車椅子ユーザーから「実際の細かい段差がわからない」「段差があれば行くのを躊躇す る」という声が挙がっている調査結果も報告されている（荒井，2019）。そこで，車椅子ユーザーにとって屋内屋 外問わず他者の助力を必要としないで移動の困難さを克服することは，車椅子ユーザーとその介助者双方の QOL の向上につながると考えられることから，溝や段差の移動を実現できる車いすの移動支援装置を提案することは 意義あるものと考える.

段差昇降可能な車いすの機構の特徵として，(a) 昇降機構を前方か後方のどちらかにアドオンしたタイプ，(b) 前 後両側にアドオンしたタイプ, (c) その他専用機に大別される.

(a)の片側アドオン型の代表的な昇段シーケンスとして，車いす前キャスターを段差面に着地させた後，車いす のメイン車輪を段差のエッジに沿って乗り上げる一連の動作が提案されている。例えば, 深谷（深谷, 2017）に よれば $55 \mathrm{~mm}$ の段差踏破の報告があるが, 後輪乗り上げ時にかなりの力が必要なことや後方への転倒リスクが生 じるなどの課題を挙げている，この転倒リスクを防止するため，森ら（森他，2014）は伸縮リンク機構による昇 降シーケンスを提案しているが，段差乗り上げと段差下りの際に後方への傾斜（いわゆるキャスター上げ）が必 要となるため搭乗者の姿勢変化や恐怖感の抑制が考慮されていない点や, 事前に段差高さを計測しておく必要が あるなど運用面でやや問題がある．宗方ら（宗方，和田，2016）も同様な機構で段差昇降を実現しているが，段 差情報を専用センサで計測する必要がある点や降段時間が長くかかることからコスト面や機動性の面で最適であ るとはいえない.

一方，(b) の両側機構型の先行研究として，芝崎（芝崎，1995）は前方にアーム機構，後方に伸縮機構を備えた 車椅子を提案しているが，昇降時に車体姿勢が傾斜する点や降段の際「しりもち」をつくことになるため，搭乗 者への衝撃や機器の破損の恐れが懸念される. 山崎ら（山崎他，2002）は伸縮機構装置を前後に配置し，それら を順次駆動することで水平姿勢のまま昇降移動を実現するシーケンスを提案しているが, 昇降移動の際, 後方か ら介助者の昇降操縦および手押し操作が必要であることから単身での運用面で課題が残る.

これらアドオン型以外の (c) の段差対応モビリティとして, 変形クローラ機構（菅原他, 2011）や脚式 4 輪機構 （Nakajima，2015）を特徴とする移動体が提案されている．これらは優れた不整地移動性能を有しているが，専用 機であるため機構や制御の複雑さ，およびそれにともなうコスト面の観点から必ずしも車椅子ユーザーが所望す る最適解であるとはいえない.

そこで本論文では，既存の車椅子との親和性を考慮してアドオン型の段差昇降機構とその制御法を提案する. 機 構の配置は, 車椅子搭乗者の単身操作でかつ水平姿勢を保持したままの移動を実現する目的で (b) の両側機構型と する．本論文では実用面を考慮して次の 2 つの特徵からなる昇降シーケンスを提案する.

（1）車椅子ユーザーが初めてその段差に遭遇する状況を想定して，段差高さの事前計測は不要とする.

(2) 水平姿勢を保持したまま段差への乗り降りをソフトランディングで完了する.

具体的には（1）を実現するために外乱オブザーバ（Nakao et al., 1987，村上他, 1990）を応用した段差検知とそ の高さ推定法を提案する. (2)（1）で推定された高さに対して水平姿勢を実現する昇降モデルを構築する。一般的 に機械系の制御対象にとって，外部との物理的衝突や外乱は忌避されるかそれを抑制するような補償器を組み込 むよう設計される。一方，本論文の目的は，アクチュエータを段差に能動的に衝突をすることで段差の高さ計測 機能と段差移動機能の両方を実現する制御システムを設計することにある. 本論文では，このような機能を併せ 持つ駆動ユニットを 2 基協調制御することで, 段差環境に対して車台の水平姿勢保持や, 降下時の落下の衝撃を 受けることなくソフトランディングを実現する移動体を提案する.

本論文の構成として，2 章にアドオン型昇降機構の概要を示す． 3 章では段差高さ推定法と姿勢維持運動学，外 乱オブザーバに基づく接地判定法について示す． 4 章では人搭乗時の段差昇降実験について示し, 最後に 5 章で まとめを示す。

\section{2. アドオン型昇降機構}

本論文では，市場に流通している既存の車椅子（手動・電動型は問わない）にアドオンで取り付け可能な昇降 装置の開発を目的とする．提案する昇降装置を市販の電動車いす（YAMAHA 製, $30[\mathrm{~kg}]$ ）に取り付けた全体写真 を図 1 に示す. 昇降装置の基本機構は前後 2 基のリニアアクチュエー夕（最大発生力 3000[N]@24[v]）を駆動源と 

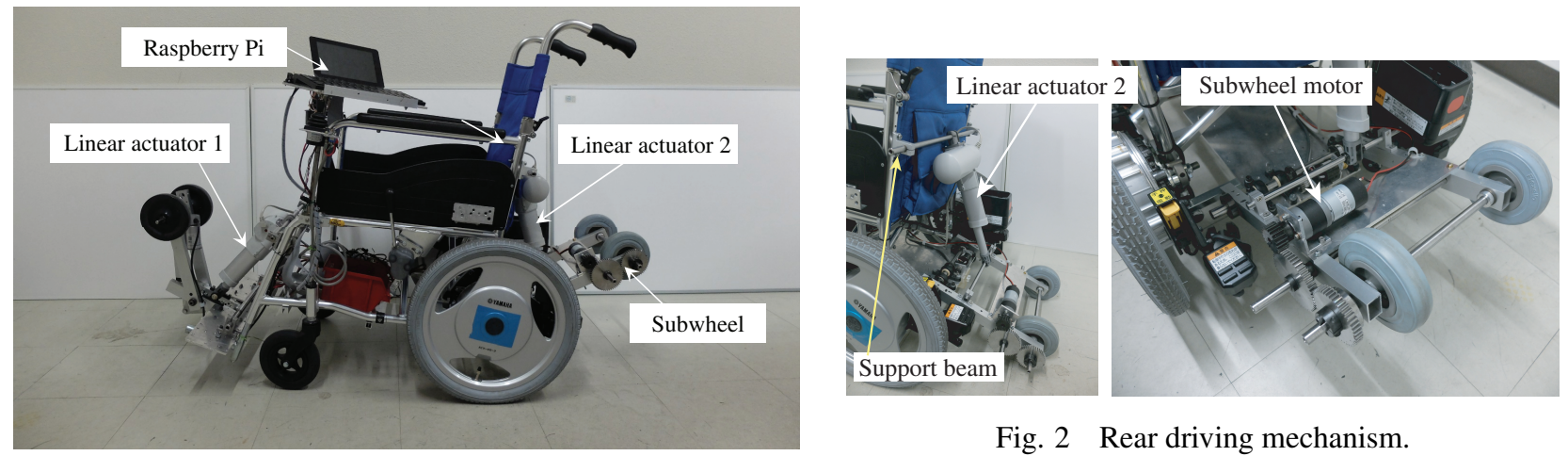

Fig. 2 Rear driving mechanism.

Fig. 1 Whole picture view of proposed wheelchair.

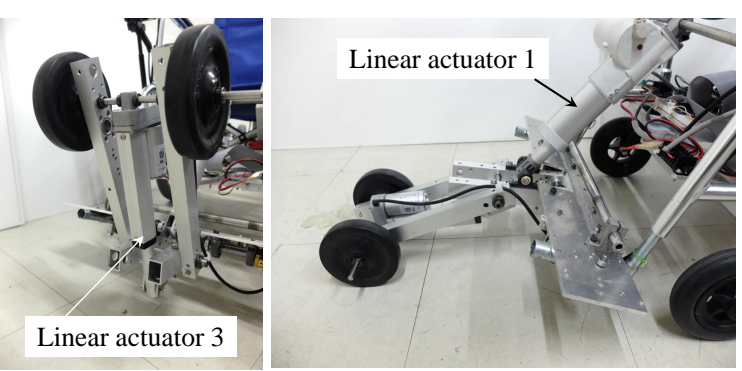

Fig. 3 Front driving mechanism.

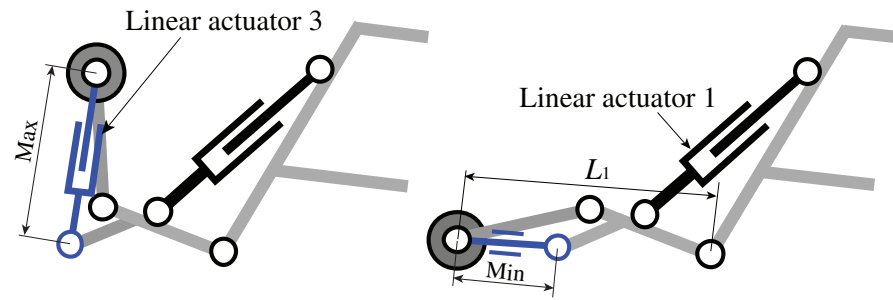

Fig. 4 Mechanism of bending and stretching for front top arm. The top of arm is stretched and bended by linear actuator1 and linear actuator3.

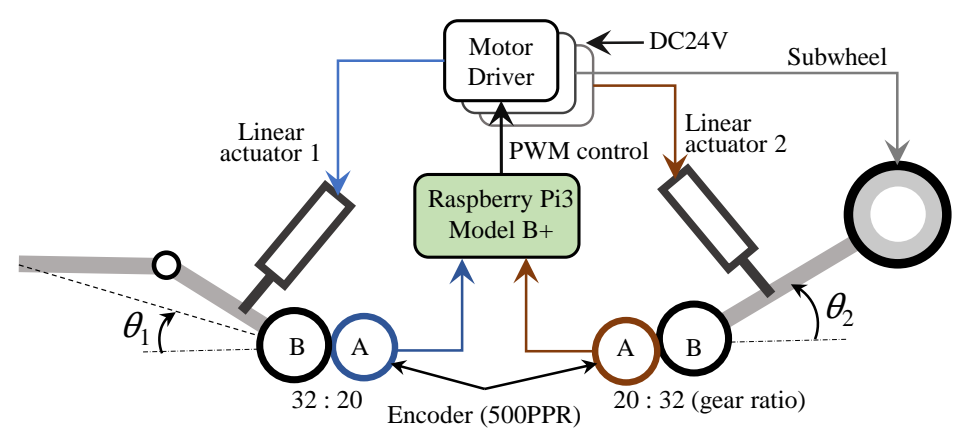

Fig. 5 Configuration of control devices. These I/O devices consist of encoders, motor drivers, battery and Raspberry Pi. Arm angle is measured by the encoder(500PPR) through the intermediary of the gear.

するアーム回転機構である。リニアアクチュエータを採用した理由は，動作速度は落ちるが耐荷重に優れている 点と, 万が一の制御信号の遮断が発生した際のアーム角度の保持機構も兼齐備えているからである. 図 2 に後ろ 側昇降機構の写真を示す. 後ろ側機構には後述するように段差面を自走するための補助駆動輪を備えている. 図 3 に前側昇降機構を示す。図 4 に示すように，バリアフリー環境で通常の車椅子として使用する際はアームを上方 に折りたたむための屈伸用の第三のリニアアクチュエータ（最大発生力750[N]@24[v]）を取り付けた。これらの 装置はコンピュータ（Raspberry Pi）により制御される。

本システムの計測制御装置の構成を図 5 に示す．計測制御機器は Raspberry Pi を用いる．エンコーダでアーム角 度を計測し，モータードライバで各アクチュエータを駆動する。モータードライバの給電は $24 \mathrm{v}$ バッテリーを内 蔵した。アームの角度は, ギア比 20:32 の平歯車 A と B を介してエンコーダ (500 パルス／ R, 日本電産コパル 電子 RE30E-500-213-1）を 4 派倍で計測する. 


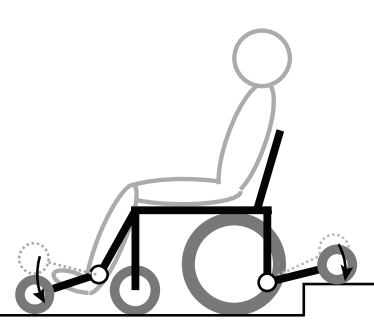

(a) Grounding arms

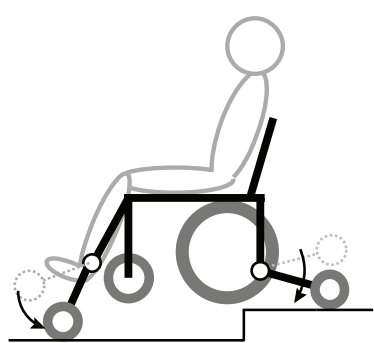

(b) Lift up

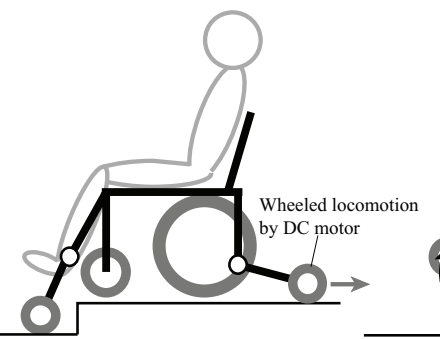

(c) Wheeled locomotion to back

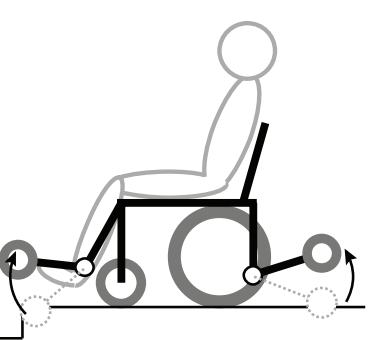

(d) Landing

Fig. 6 Sequence of ascending motion.

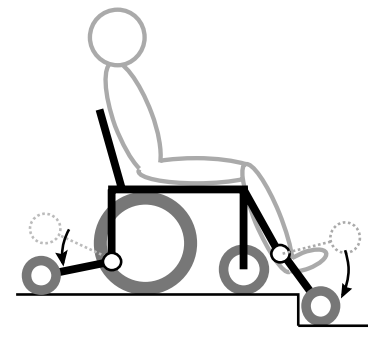

(a) Grounding arms

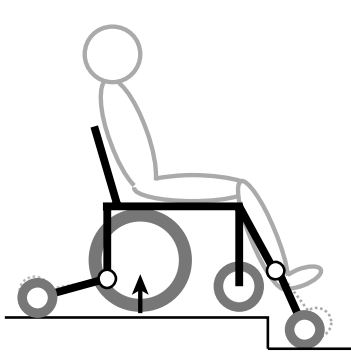

(b) Lift up

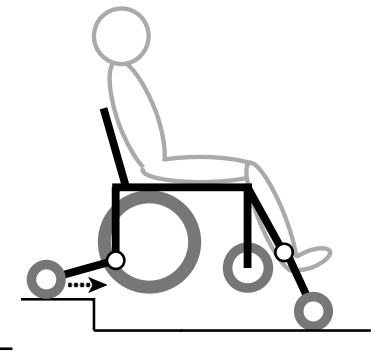

(c) Wheeled locomotion ahead

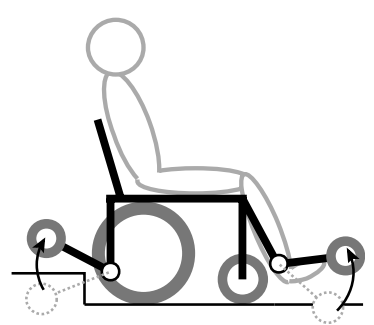

(d) Landing

Fig. 7 Sequence of descending motion.

\section{3. 高さが未知な段差に対する昇降シーケンス}

本章では，車椅子の前と後にアドオンした各アームを接地することで段差の高さ推定を行った後, 姿勢を水平 に維持しながら段差面に移動しソフトランディングまでを完了する昇降シーケンスを提案する。ささら，外乱才 ブザーバを応用することで人の目視や人の操作を介することなくアームの接地判定が実現できることを示す．図 6 および図 7 に提案する段差昇降シーケンスを示す。図 6 の昇段移動を例に取れば各フェーズは以下の通りである.

(a) 車椅子は後方から段差手前にアプローチ後, 前後のアームを接地するまで回転させる.

(b) 車椅子が所定の高さまで上昇するまで両アームを回転させる.

(c) 車椅子を (b) の高さに保持したまま補助車輪を駆動し後方に移動する.

(d) 両アームを上方に戻すことで車椅子を段上にソフトランディングさせる.

\section{$3 \cdot 1$ 接地アームモデルに基づく姿勢維持運動学}

本節では，提案する昇降シーケンスを実現するためにアーム接地時の運動学を述べる．まず議論をわかりやす くするため本論文では，アーム角度の符号を水平線を基準に上向きを正，下向きを負と定義する。また座標系の 原点を最初に遭遇する段差の角と定義する。

図 8 に降段開始時の初期姿勢を示す。ここで $H$ は段差高さ， $L_{1}$ は前側アームの長さ， $r_{1}$ は補助輪の半径, $h_{1}$ は 前側アーム支点から床面までの高さとする．座標系の原点を段差の角 $\mathrm{O}_{1}$ とおくと前側アームの最下点の高さ $y_{1}$ は

$$
y_{1}=h_{1}+L_{1} \sin \theta_{1}-r_{1}
$$

\section{と定義される。}

同様に，図 9 に昇段開始時の初期姿勢を示す。ここで $L_{2}$ は後ろ側アームの長さ， $r_{2}$ は補助輪の半径, $h_{2}$ は床面 から後ろ側アーム支点までの高さとする．座標系の原点を段差の起点 $\mathrm{O}_{2}$ とおくと後ろ側アームの最下点の高さ $y_{2}$ は

$$
y_{2}=h_{2}+L_{2} \sin \theta_{2}-r_{2}
$$

と定義される。

式 (1), 式 (2) において $r_{1}, L_{1}, h_{1}, r_{2}, L_{2}, h_{2}$ は車椅子固有の既知な寸法なので, アームの接地角 $\theta_{1}^{s}$ と $\theta_{2}^{s}$ が検 


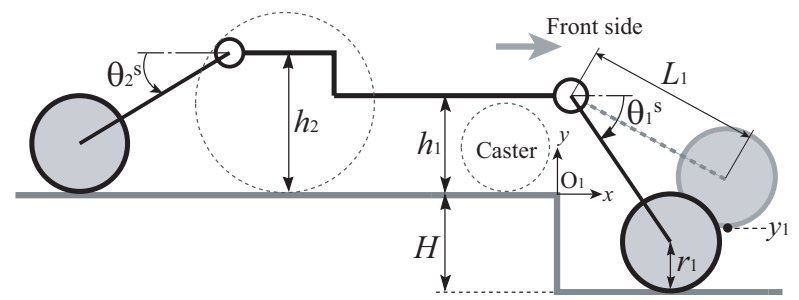

Fig. 8 Initial configuration of descending mode. The sign of the arm angle is defined as positive for upward and negative for downward with respect to the horizontal line.

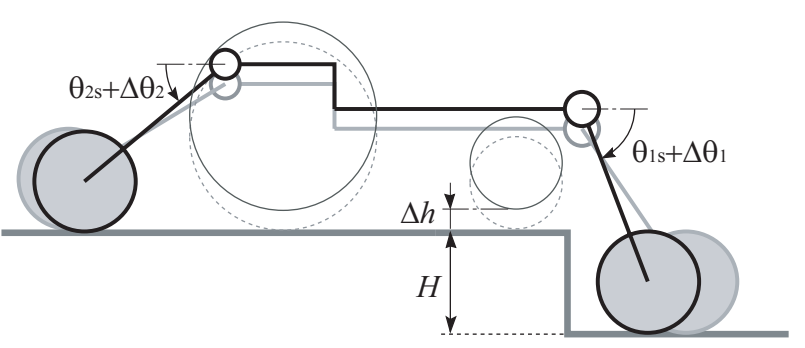

Fig. 10 Configuration of descendind mode at lifting up $\Delta h$.

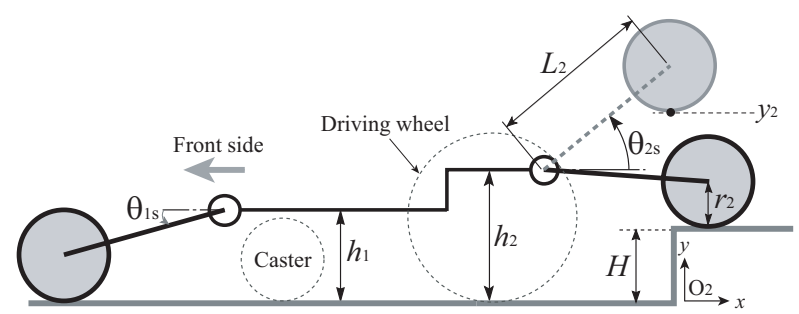

Fig. 9 Initial configuration of ascending mode. The sign of the arm angle is defined as positive for upward and negative for downward with respect to the horizontal line.

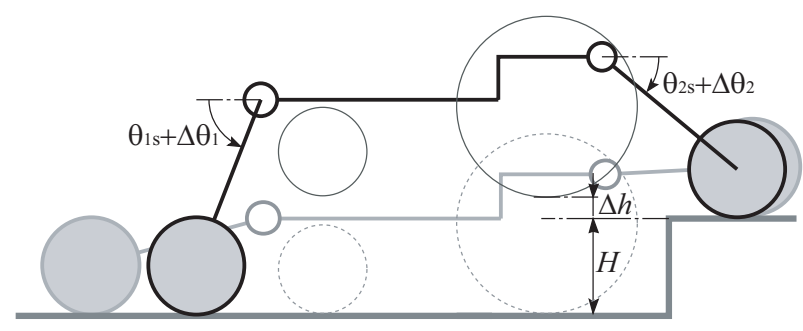

Fig. 11 Configuration of ascending mode at lifting up $H+$ $\Delta h$.
Table 1 Length of arm unit.

\begin{tabular}{c||c|c|c}
\hline & $h[\mathrm{~mm}]$ & $L[\mathrm{~mm}]$ & $r[\mathrm{~mm}]$ \\
\hline Front & 116 & 330 & 62.5 \\
\hline Rear & 183 & 280 & 62.5 \\
\hline
\end{tabular}

Table 2 System parameters of arm unit.

\begin{tabular}{c||c|c|c|c|c}
\hline & $g$ & $a$ & $J_{n}\left[\mathrm{kgm}^{2}\right]$ & $D_{n}[\mathrm{Nms} / \mathrm{rad}]$ & $K_{n}$ \\
\hline Front & 15.0 & 10.0 & 6.05 & 1.55 & 0.0111 \\
\hline Rear & 12.0 & 10.0 & 4.96 & 1.55 & 0.0116 \\
\hline
\end{tabular}

出できれば，段差の高さは容易に推定できることがわかる。なお，実機ではアーム接地角度はエンコーダより計 測される。

次に, 図 6(b) および図 7(b) に示すリフトアップを実現する運動学モデルを示す。初期姿勢から図 10 および図 11 のように車椅子の姿勢を水平に保持したままリフトアップを実現するアーム角度の導出について述べる。前及 び後ろアームが接地することによって推定される高さをそれぞれ $\hat{H}_{1}, \hat{H}_{2}$ とおけば

$$
\left\{\begin{array}{l}
\hat{H}_{1}=h_{1}+L_{1} \sin \theta_{1}^{s}-r_{1} \\
\hat{H}_{2}=h_{2}+L_{2} \sin \theta_{2}^{s}-r_{2}
\end{array}\right.
$$

と算出される。ささに車椅子が高さ $\Delta h$ だけリフトアップしたとき，前後のアームの変化量をそれぞれ $\Delta \theta_{1}, \Delta \theta_{2}$ と おけば，次式が成り立つ。

$$
\left\{\begin{array}{l}
\hat{H}_{1}-\Delta h=h_{1}+L_{1} \sin \left(\theta_{1}^{s}+\Delta \theta_{1}\right)-r_{1} \\
\hat{H}_{2}-\Delta h=h_{2}+L_{2} \sin \left(\theta_{2}^{s}+\Delta \theta_{2}\right)-r_{2}
\end{array}\right.
$$

この関係から，昇段および降段時，リフトアップさせたい高さ $\Delta h$ を与えれば，これを実現するアーム角度の変化 量は以下のように導出できる.

$$
\left\{\begin{array}{l}
\Delta \theta_{1}=\sin ^{-1}\left(\frac{\hat{H}_{1}-\Delta h-h_{1}+r_{1}}{L_{1}}\right)-\theta_{1}^{s} \\
\Delta \theta_{2}=\sin ^{-1}\left(\frac{\hat{H}_{2}-\Delta h-h_{2}+r_{2}}{L_{2}}\right)-\theta_{2}^{s}
\end{array}\right.
$$

表 1 に実機アームユニットの諸元を示す. 


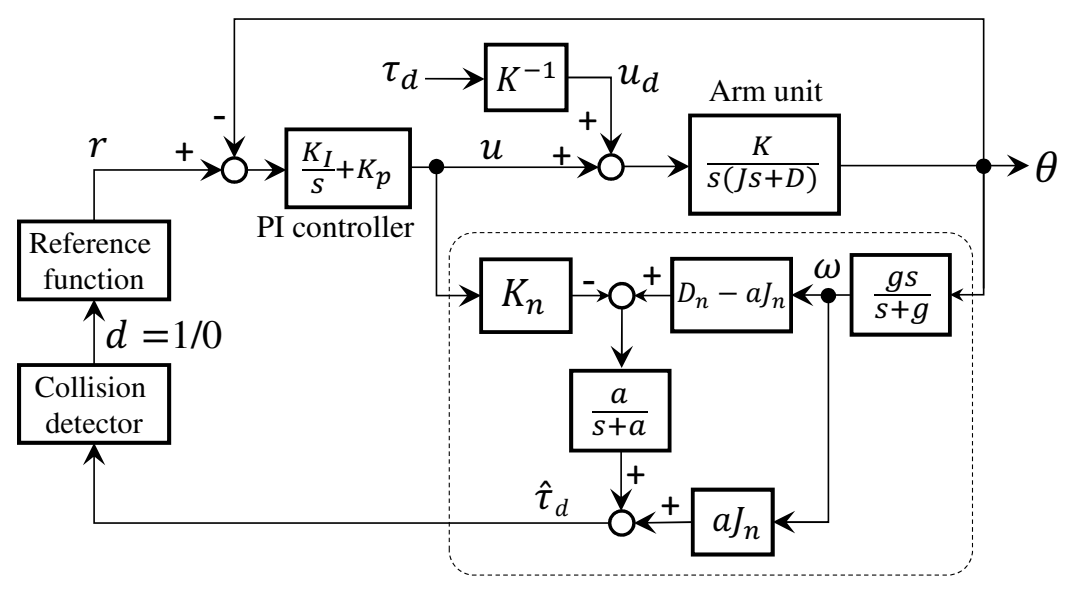

Fig. 12 Arm control system with collision detection by disturbance observer.

\section{$3 \cdot 2$ 外乱オブザーバに基づく接地判定}

本論文では車椅子の昇降動作において人の目視や操作の介入を必要としないで，段差移動を実現することを目 的とする，昇降シーケンス図 6(a) および図 7(a) に示すように初期状態からアームが接地するとき，搭乗者は前ま たは後ろ側のアームは死角となり, 搭乗者の操作のみで昇段移動を実行することは, 多段操作による誤操作やむ だ時間の累積などの理由から有用とはいえない，そこで，本節ではアームが床面に接地するかどうかの検知法と して，外乱オブザーバを応用した自動アーム接地判定法を提案する.

アームユニットの駆動源は DC モータであるので, リニアアクチュエータの入力電圧 $u$ とアーム回転角 $\theta$ の伝 達関数を

$$
G(s)=\frac{\Theta(s)}{U(s)}=\frac{K}{s(J s+D)}
$$

とおく。ここで $K$ は定数ゲイン, $J$ はアームの慣性モーメント， $D$ は粘性摩擦係数とおき，これらは実験的に求 める定数とする。一般にモータトルクに対する外乱は次式で推定される.

$$
\hat{\tau}_{d}=\frac{a}{s+a}\left\{\left(J_{n} s+D_{n}\right) \omega-K_{n} u\right\}
$$

ここで $a$ は適当なローパスフィルタの極とし $, K_{n}, J_{n}, D_{n}$ はそれぞれ $K, J, D$ のノナル值とおく.また実機では, アームの角速度 $\omega$ はエンコーダの微分演算とローパスフィルタを用いて次式で算出する.

$$
\omega=\frac{g}{s+g} s \theta
$$

式（7）では角速度の微分を演算することになるため，ノイズの影響により外乱推定の精度が落ちてしまう。そこ で，角速度の微分演算を回避するため式（7）を次式のように変形する.

$$
\hat{\tau}_{d}=\frac{a}{s+a}\left\{\left(D_{n}-a J_{n}\right) \omega-K_{n} u\right\}+a J_{n} \omega
$$

本論文ではさらに，この外乱推定值がある任意の閾值 $\gamma$ 以上であればアーム接地とみなすものとする。 その接地 判定パラメータ $d$ は以下の閾値判定で定義する.

$$
d= \begin{cases}1 & \left(\hat{\tau}_{d} \geq \gamma\right) \\ 0 & \text { (otherwise) }\end{cases}
$$

以上の外乱検知システムを図 12 にまとめる。図中 'Reference function’ はアーム接地モードとリフトアップモー ドに対する目標值関数とおき，こ扎は接地検知パラメー夕 $d$ によって切り替える。 また'PI controller'により目標 值追従制御系を組み込む。アーム駆動ユニットのシステムパラメータは表 2 で与えた. 


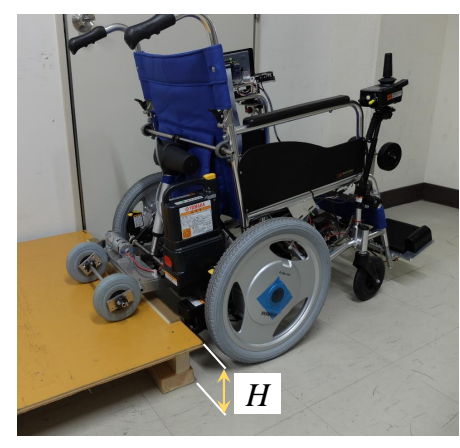

(a) Ascending mode

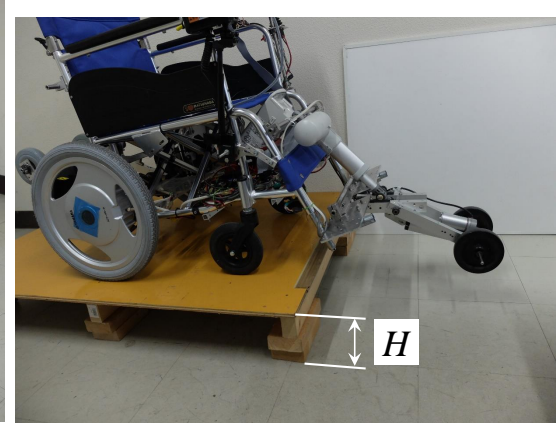

(b) Descending mode

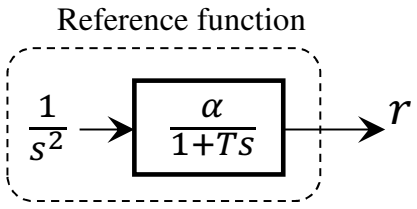

Fig. 14 Ramp function with time lag $T$ in grounding arms motion.

Fig. 13 Experiment facility.

\section{$3 \cdot 3$ 接地検知検証}

前節で提案した外乱オブザーバによる接地検知および段差高さ推定の精度検証の実験を行った。実験は，図 13 に示すように昇段モードと降段モードについて高さ $H$ を変えて実施した，昇降シーケンス図 6(a) および図 7(a)に おけるアームの目標值として, 図 14 に示すランプ関数を一次遅れ要素に通した時間関数

$$
r(t)=\alpha\left\{t-T\left(1-e^{-\frac{t}{T}}\right)\right\}+\theta(0)
$$

を入力として与える。ここで $\alpha$ はランプ関数の勾配 $[\mathrm{rad} / \mathrm{s}]$ とおく.

実験は 2 種類の高さ $H=100 \mathrm{~mm}$ と $H=175 \mathrm{~mm}$ に対して, ともに昇段モードと降段モードで行った. $H=100$ $\mathrm{mm}$ とした理由は, 鉄道駅のプラットホームと車両乗降口の高さは, 車両の形式によっては最大 $75 \mathrm{~mm} の$ 高さが 生じる点を考慮した（国土交通省鉄道局，2020）。また $H=175 \mathrm{~mm}$ とした理由は，標準仕様のノンステップバス の乗降口高さ $285 \mathrm{~mm}$ 以下とバスベイ高さ（バス停留所の縁石高さ） $150 \mathrm{~mm}$ との差 $=135 \mathrm{~mm}$ を考慮した（国土 交通省標準仕様ノンステップバス，2020）。

本システムでは，外乱推定值が閾值を超えたあとはそのアームの駆動を停止するシーケンスを組み込んでいる. この停止機能は前・後アームに独立して組み込んでいるので, ぞちらかが先に停止しても, 残りの一方は外乱検 知するまでアーム駆動を継続する有用性をもつ.

図 15 に $H=100 \mathrm{~mm}$ に対する実験結果を，図 16 に $H=175 \mathrm{~mm}$ に対する実験結果を示す．各図において，(a), (b), (c) は昇段モードに対応し，(d), (e), (f) は降段モードに対応する. 図 (a) と (d) はアームの角度応答を示す. 破 線はアーム制御系におけるランプ関数の目標值であり, その勾配は $\alpha=0.349 \mathrm{rad} / \mathrm{s}=20 \mathrm{deg} / \mathrm{s}$ と与えた. 図 (b) と (e) は外乱オブザーバで推定した外乱トルクであり，外乱検知の式（10）の閾值は $\gamma=0.6$ と与えた. 図 (c) と (f) は式（1）と式（2）ょり計算した前後のアームの最下点高さである. 本実験は昇降シーケンスにおける接地検知 の有効性を示したもので, 接地以降の応答は 4 章の結果を参照されたい.

段差検知機能と段差高さ推定精度について考察する。表 3 には，図 15 と図 16 の実験デー夕の解析結果を示す. この表において， $t_{1}^{s}, t_{2}^{s}$ はそれぞれ前アーム，後ろアームが外乱を検知した時刻とおく（図 15(b) 参照）。また $\theta_{1}^{s}$, $\theta_{2}^{s}$ はそのときのアーム角度とおき， $\hat{H}_{1}, \hat{H}_{2}$ は段差の推定値とおく，高さ推定の結果より，実際に設定した段差高 さに対して最大誤差 $2.57 \mathrm{~mm}$ の精度で推定できていることが見て取れる. したがって本検証結果より, 高さが未 知な段差であっても, 外乱推定を応用した段差検知機能により, 実際の段差高さを許容範囲内の誤差で推定可能で あることを確認した。

Table 3 Analysis results for step height after disturbance detection.

\begin{tabular}{cl||rr|rr|rr}
\hline Step height & mod & $t_{1}^{s}[\mathrm{~s}]$ & $t_{2}^{s}[\mathrm{~s}]$ & $\theta_{1}^{s}\left[^{\circ}\right]$ & $\theta_{2}^{s}\left[^{\circ}\right]$ & $\hat{H}_{1}[\mathrm{~mm}]$ & $\hat{H}_{2}[\mathrm{~mm}]$ \\
\hline \multirow{2}{*}{$100[\mathrm{~mm}]$} & ascend & 3.1 & 5.3 & -8.80 & -4.39 & 2.56 & 99.08 \\
& descend & 5.7 & 9.1 & -27.36 & -25.31 & -98.16 & 0.79 \\
\hline \multirow{2}{*}{$175[\mathrm{~mm}]$} & ascend & 2.6 & 3.0 & -8.16 & 10.69 & 5.63 & 172.43 \\
& descend & 7.8 & 9.0 & -43.80 & -24.86 & -174.91 & 2.78 \\
\hline
\end{tabular}




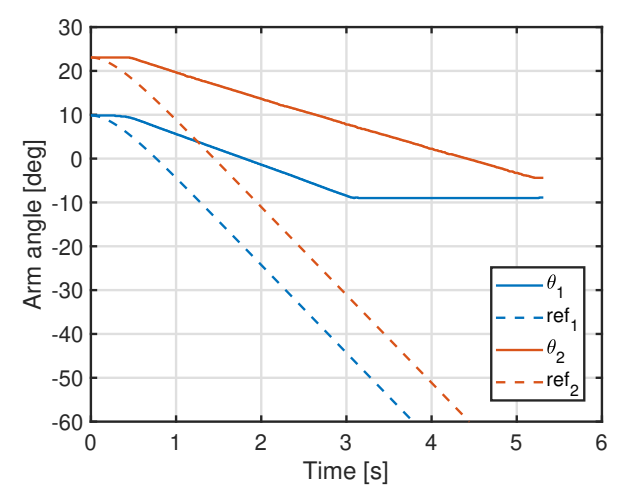

(a) Arm angle response

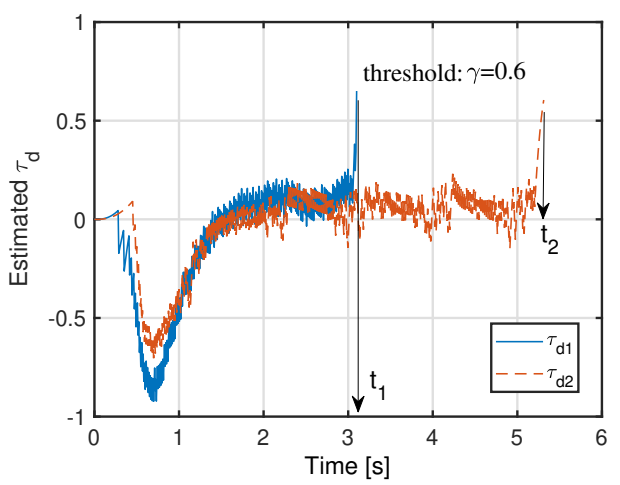

(b) Estimated disturbance torque

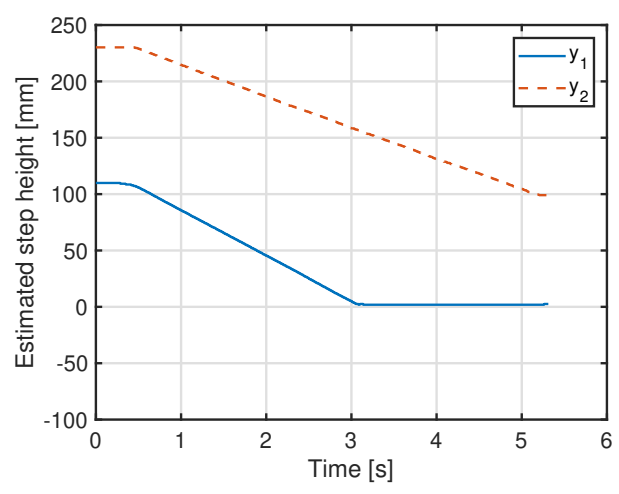

(c) Estimated step height

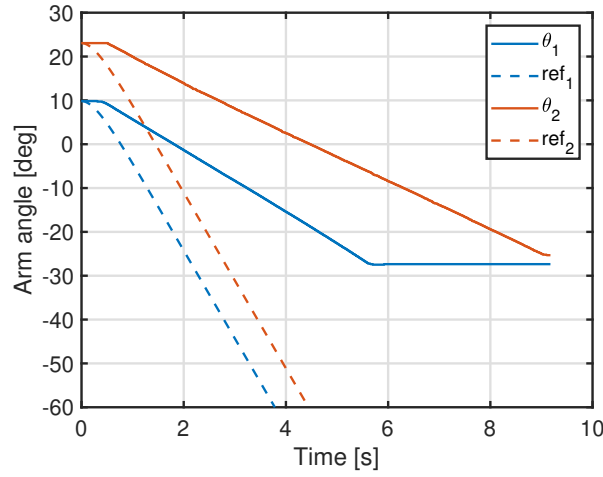

(d) Arm angle response

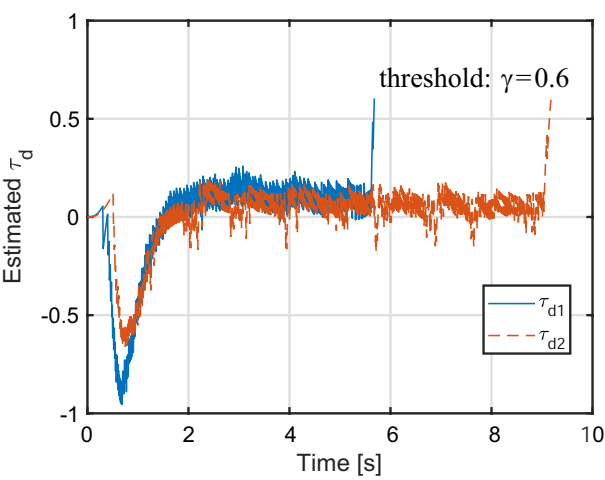

(e) Estimated disturbance torque

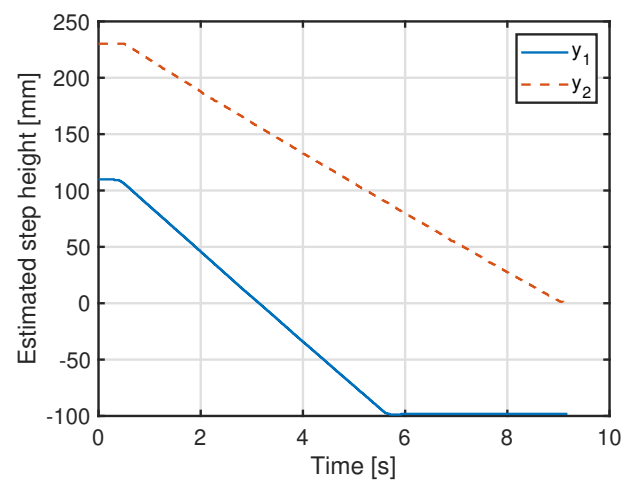

(f) Estimated step height

Fig. 15 Experimental results where (a) (c) are ascending mode and (d) $\sim(f)$ are descending mode for step height $H=100 \mathrm{~mm}$. From the estimated torque results (b), it can be seen that spike-like disturbances occur at times $t_{1}=3.1 \mathrm{~s}$ and $t_{2}=5.3 \mathrm{~s}$. The estimated step heights at this time are calculated as $\hat{H}_{1}=2.56 \mathrm{~mm}$ and $\hat{H}_{2}=-98.16 \mathrm{~mm}$, respectively, and these are close to the true values. Similarly from the estimated torque results (e), it can be seen that spike-like disturbances occur at times $t_{1}=5.7 \mathrm{~s}$ and $t_{2}=9.1 \mathrm{~s}$. The estimated step heights at this time are calculated as $\hat{H}_{1}=-98.16 \mathrm{~mm}$ and $\hat{H}_{2}=0.79 \mathrm{~mm}$, respectively, and these are close to the true values.

\section{4. 段差昇降移動実験}

段差接地後の昇降動作を実現するにあたり，本論文では車椅子本体が水平姿勢を保持したままの昇降移動を目 的とする。このような動作を実現するために本章では，前・後アームに対して，それらが協調することで車椅子 を床面上から任意の高さにリフトアップする計画法を提案する.

上昇中の搭乗者への初速度および終端速度を抑えるためにリフトアップ高さ $\Delta h$ を式（12）で与える.

$$
\Delta h(t)=A\left(1-\cos \frac{\pi}{T_{f}} t\right), \quad\left(0 \leq t \leq T_{f}\right)
$$




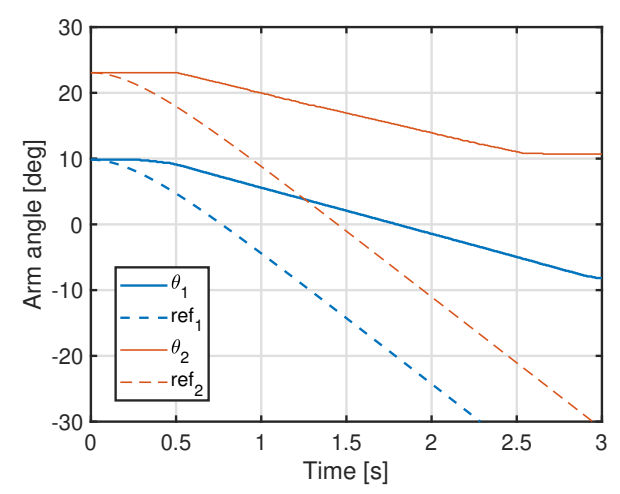

(a) Arm angle response

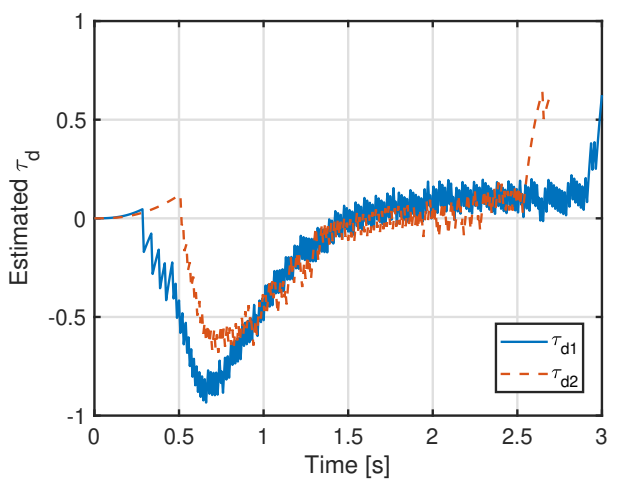

(b) Estimated disturbance torque

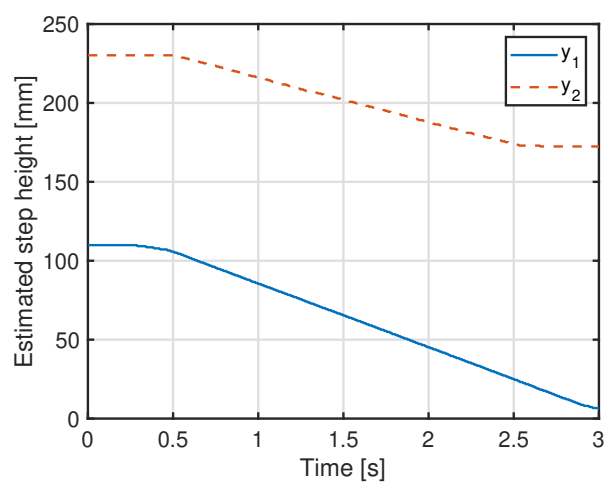

(c) Estimated step height

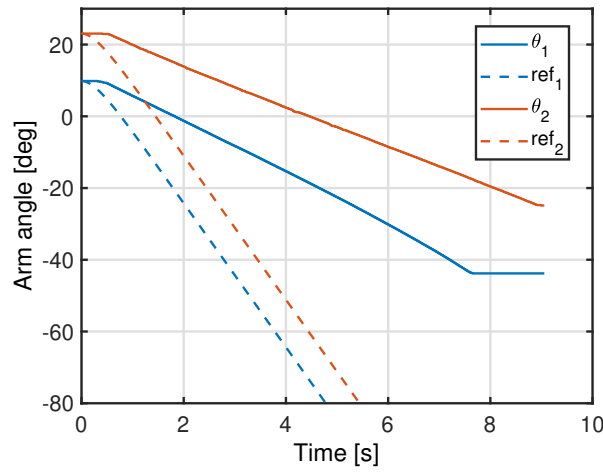

(d) Arm angle response

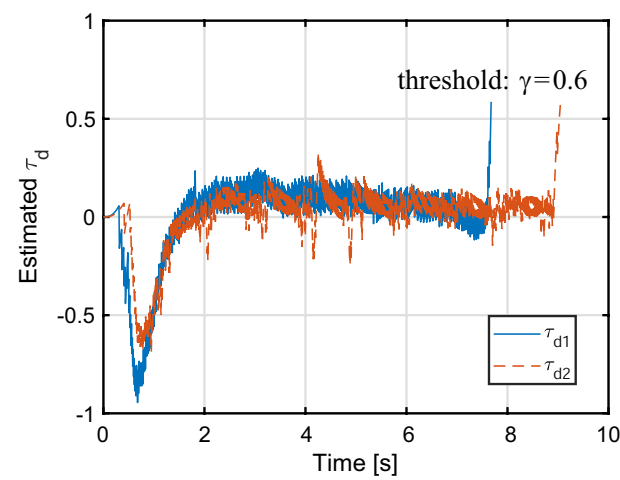

(e) Estimated disturbance torque

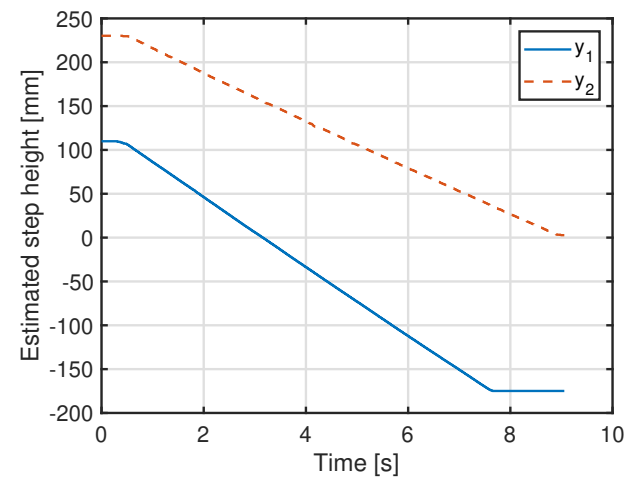

(f) Estimated step height

Fig. 16 Experimental results where (a) (c) are ascending mode and (d) $\sim(f)$ are descending mode for step height $H=175 \mathrm{~mm}$ From the estimated torque results (b), it can be seen that spike-like disturbances occur at times $t_{1}=2.6 \mathrm{~s}$ and $t_{2}=3.0 \mathrm{~s}$. The estimated step heights at this time are calculated as $\hat{H}_{1}=5.63 \mathrm{~mm}$ and $\hat{H}_{2}=172.43 \mathrm{~mm}$, respectively, and these are close to the true values. Similarly from the estimated torque results (e), it can be seen that spike-like disturbances occur at times $t_{1}=7.8 \mathrm{~s}$ and $t_{2}=9.0 \mathrm{~s}$. The estimated step heights at this time are calculated as $\hat{H}_{1}=-174.91 \mathrm{~mm}$ and $\hat{H}_{2}=2.78 \mathrm{~mm}$, respectively, and these are close to the true values.

これを時間で微分すれば上昇速度は次式となり，初速度と終端速度はともに0が実現できる。

$$
\frac{d \Delta h}{d t}=A \frac{\pi}{t_{f}} \sin \frac{\pi}{T_{f}} t
$$

図 17 に正規化した式（12）と式（13）の波形を示す。本論文では，アームが段差接地のトリガー $d=1$ を検知後 は，式（12）の上昇変数 $\Delta h$ を式（5）に代入することで前・後アームの目標角度を求めるものとする。計算例と して図 18 に, 段差高さ $H=130 \mathrm{~mm}$ に対してリフトアップ高さ $\Delta h=30 \mathrm{~mm}$ を実現するときの前・後アームのシ ミュレーション結果を示す（ただし，時間軸は正規化している）。なお同図には昇段モードと降段モードの 2 種類 の計算例を示す。 


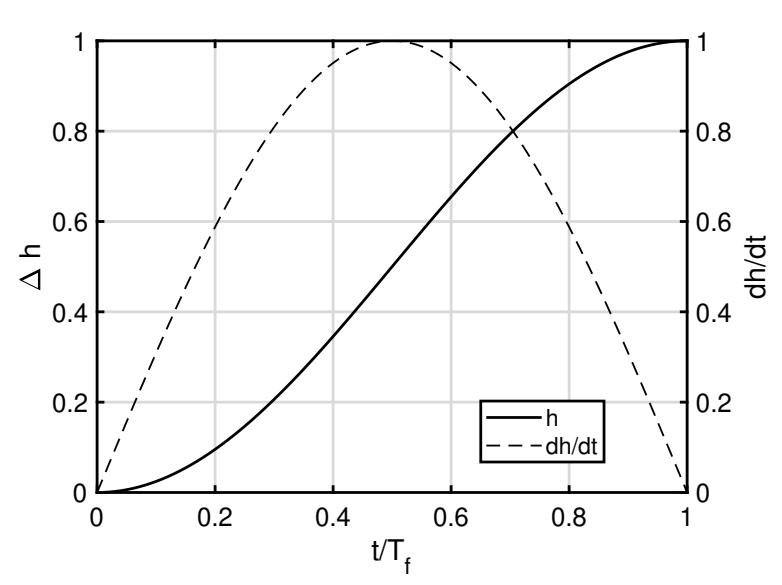

Fig. 17 Normalized lift up displacement and its derivation.

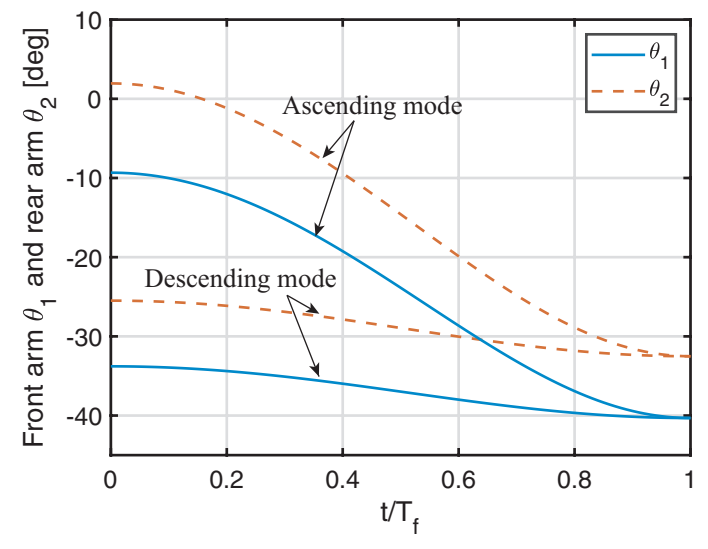

Fig. 18 Front and rear arm variations corresponding to lifting up height of $30[\mathrm{~mm}]$ in Eq.(12) in asceding/descending mode.

段差の昇降移動実験に関して以下の条件下で実施した。制御系プログラムは Raspberry Pi3 Model B+に実装した.

1. 搭乗者は体重 $55 \mathrm{~kg}$ の成人男性.

2. 段差の高さは $H=140 \mathrm{~mm}$.

3. 搭乗者には段差の高さは未知とする.

4. 搭乗者は段差の目視や昇降の手動操作は行わない.

図 19 に昇段実験の一連のスナップショットを示す，昇段移動では，搭乗者はバック走行で段差手前まで操縦し た後，制御用 PC に動作開始のトリガーを送る．図 20(a) は，動作開始 (i) から昇段動作を経て再び初期状態 (v) に 復帰するまでのアームの応答を示したものである（前アームの応答 $\theta_{1}$ が $t=22 \mathrm{~s}$ 付近で急激に変化しているの は，エンコーダの計測ノイズの影響と思われる)。図20(b) は，図20(a)の応答を基に式（1）および式（2）で算 出したアーム最下点を示す。この図 20(b) の応答の中で，前・後アームが接地を検知した時刻はそれぞれ， $t_{1}^{s}=4$ $\mathrm{s}, t_{2}^{s}=4.5 \mathrm{~s}$ と読み取れる.この時刻における段差高さは $\hat{H}_{1}=2 \mathrm{~mm}, \hat{H}_{2}=136.4 \mathrm{~mm}$ と算出され, 接地面の真值 $\left(H_{1}=0, H_{2}=140\right)$ に近い值が推定できていることがわかる. $t=5 \sim 25 \mathrm{~s}$ にかけてリフトアップ制御 (iii) および 補助輪を駆動して段上への走行 (iv) を実行する. $t=25 \mathrm{~s}$ 以降はアームを等速で初期位置に戻すことでソフトラン ディング (v)を完了する。

図 21 に降段実験の一連のスナップショットを示す，降段移動では，搭乗者は前進走行で段差手前まで操縦した 後, 制御用 PC に動作開始のトリガーを送る. 図 22(a) は, 動作開始 (i) から昇段動作を経て再び初期状態 (v) に 復帰するまでのアームの応答を示したものである，図 22(b) は，図22(a) の応答を基に式（1）および式（2）で算 出したアーム最下点を示す。この図 22(b) の応答の中で，前・後アームが接地を検知した時刻はそれぞれ， $t_{1}^{s}=6$ $\mathrm{s}, t_{2}^{s}=9 \mathrm{~s}$ と読み取れる。この時刻における段差高さは $\hat{H}_{1}=-142.4 \mathrm{~mm}, \hat{H}_{2}=1.5 \mathrm{~mm}$ と算出され，接地面の真值 $\left(H_{1}=-140, H_{2}=0\right)$ に近い值が推定できていることがわかる. $t=10 \sim 27 \mathrm{~s}$ にかけてリフトアップ制御 (iii) およ び補助輪を駆動して段の端まで自立走行 (iv) を実行する. $t=27 \mathrm{~s}$ 以降はアームを等速で初期位置に戻すことでソ フトランディング (v) を完了する.

\section{5. 結 言}

本論文では，車椅子利用者が単身操作で段差移動を可能とする昇降機構とその制御法を提案した。提案する昇 降機構は既存の車椅子に取り付け可能なアームユニット型とする。この機構に対して外乱推定オブザーバを応用 した段差検知法を実装した結果，人の目視に頼ることなく最大 $175 \mathrm{~mm}$ の段差を検知し，かつ専用のセンサを用 いることなく段差の高さを許容誤差以内で推定できることを示した。また接地後のアーム機構に対して，車椅子 本体の姿勢を水平に保持したまま段差昇降を実現するアームの運動モデルを実装した結果, 実際に体重 $55 \mathrm{~kg}$ の成 人男性が搭乗して高さ $140 \mathrm{~mm}$ の段差移動が可能であることを確認した。

しかしながら，搭乗者体重が $65 \mathrm{~kg}$ 以上では昇降ユニットのジャッキポイントにたわみが生じたため，支持パイ 


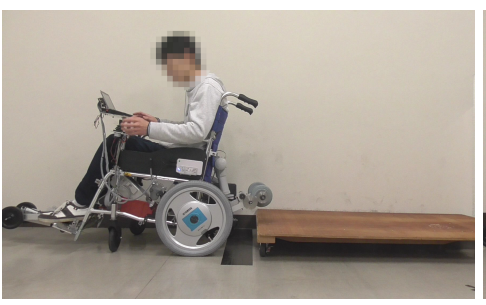

(i) Initial state

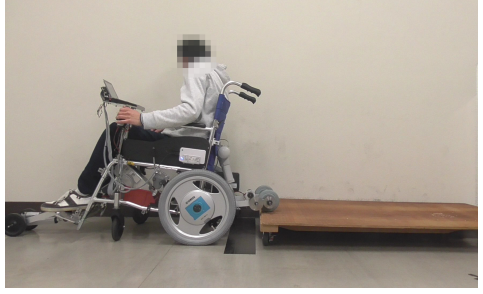

(ii) Grounding arms

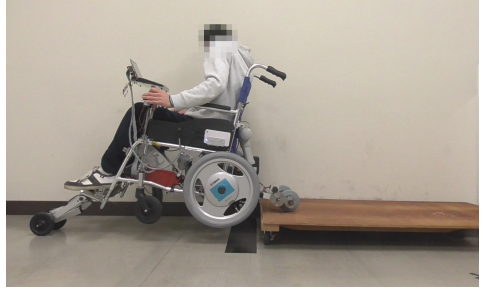

(iii) Lift up $\hat{H}+\Delta h$

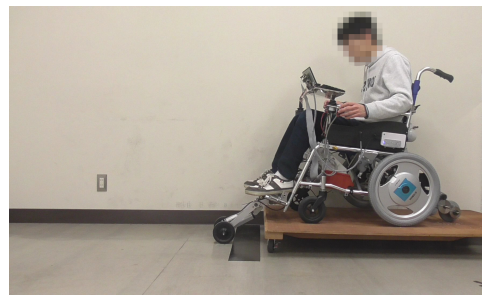

(iv) Wheeled locomotion to back

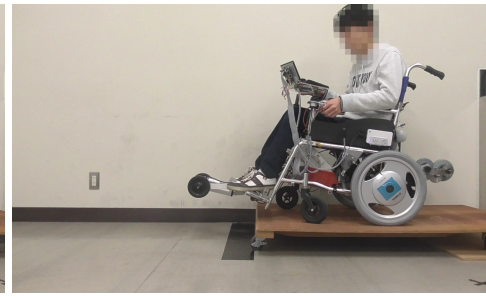

(v) Landing

Fig. 19 Snapshots of a series of ascending experiment $H=140 \mathrm{~mm}$.

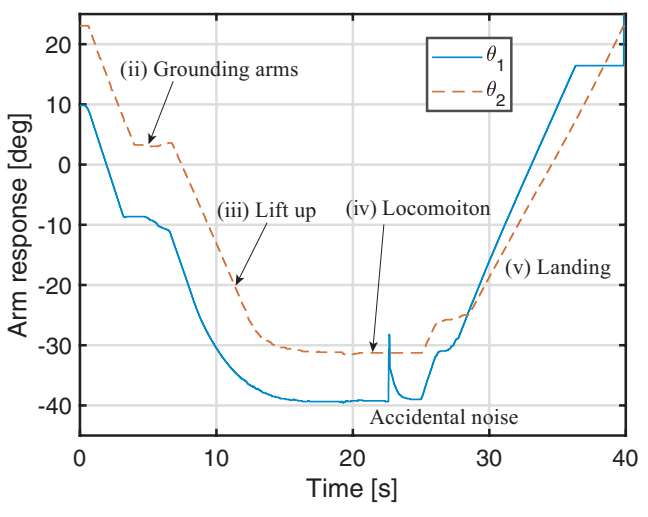

(a) Arm angle

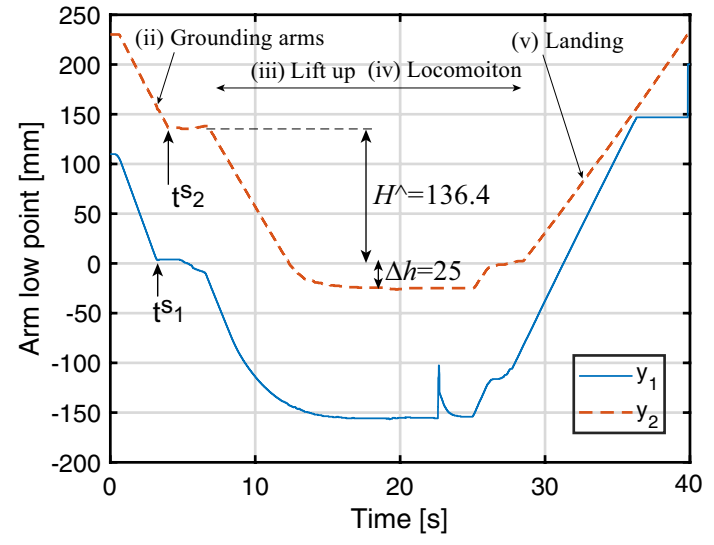

(b) Arm low point

Fig. 20 Experimantal results of arm angle and arm low points in ascending mod where (i) (v) are correponding to Fig.19. After the start of operation, both arms descend at a constant speed due to the ramp input, and the responses of arm and its low point remain constant at times of about form 4 [s] to 7 [s]. These results confirmed that the front and rear arms must be in contact with the ground. Then the step height is calculated as $\hat{H}_{1}=2 \mathrm{~mm}, \hat{H}_{2}=136.4 \mathrm{~mm}$, so it can be seen that a value close to the true value $\left(H_{1}=0, H_{2}=140\right)$ of the ground plane can be estimated.

プの剛性をより高いものに変更するか, リニアアクチュエーターを複数台に増やしてジャッキポイントの荷重を分 散させるなどの対策が必要と思われる.

本昇降システムは，車いす搭乗者が，介助を受けることなく鉄道やノンステップバスなどの公共交通車両の乗 降を実現する有効なデバイスとして活用が期待できる。今後はこのような公共交通車両の乗降検証や安全面の対 策を課題とする. 


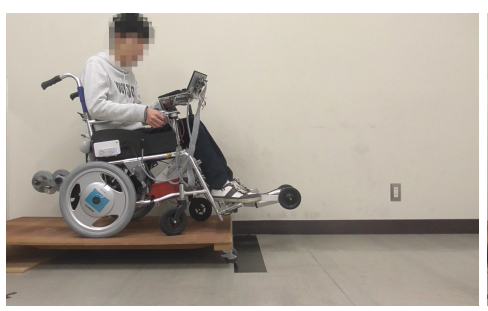

(i) Initial state

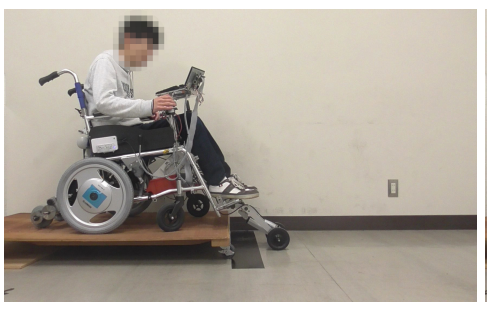

(ii) Grounding arms

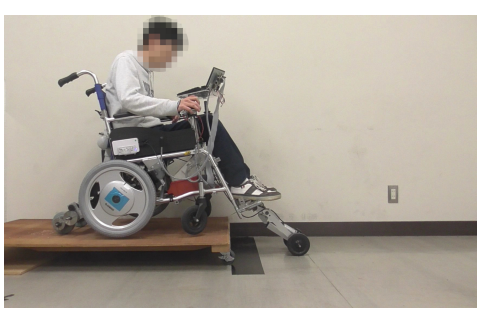

(iii) Lift up $\Delta h=25 \mathrm{~mm}$

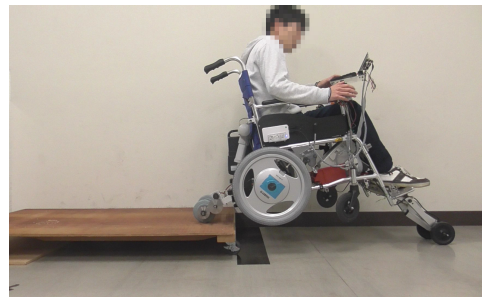

(iv) Wheeled locomotion ahead

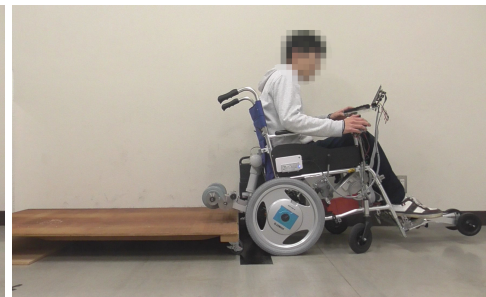

(v) Landing

Fig. 21 Snapshots of a series of descending experiment at $H=140 \mathrm{~mm}$.

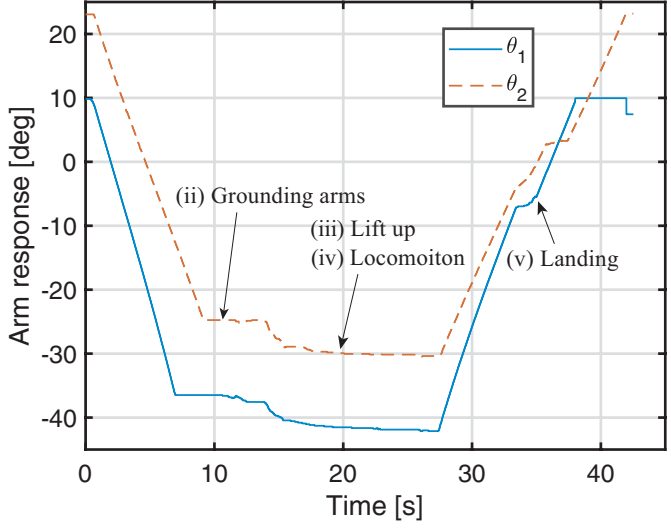

(a) Arm angle

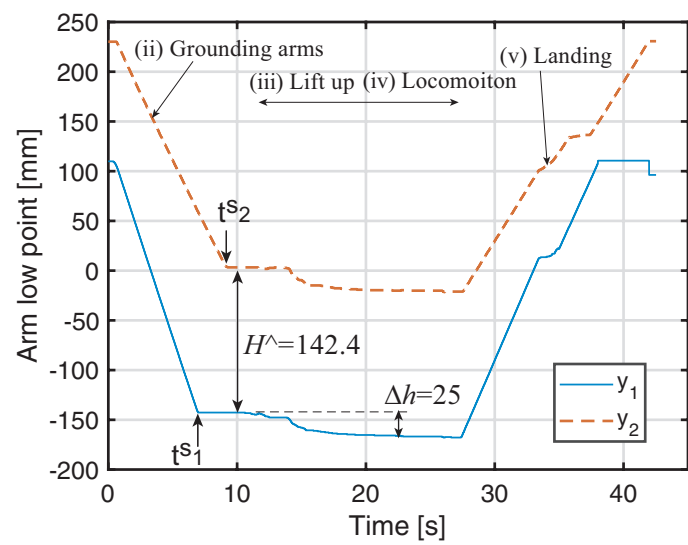

(b) Arm low point

Fig. 22 Experimantal results of arm angle and arm low points in descending mod where (i) $\sim(v)$ are correponding to Fig.21. After the start of operation, both arms descend at a constant speed due to the ramp input, and the responses of arm and its low point remain constant at times of about from 7[s] to 14 [s]. These results confirmed that both arms must be in contact with the ground. Then the step height is calculated as $y_{1}=-142 \mathrm{~mm}, y_{2}=1.5 \mathrm{~mm}$, so a value close to the true value $\left(y_{1}=-140, y_{2}=0\right)$ of the ground plane can be estimated. Also, from time $14 \mathrm{~s}$ to $27 \mathrm{~s}$, it is confirmed that a lift of $25 \mathrm{~mm}$ is realized.

\section{文献}

荒井雅代，車椅子ユーザーの交通に関する真に役立つバリアフリー情報，社会デザイン学会誌，Vol.10, No.1 (2019), pp.100-110.

電動車いす安全普及協会, available form < https://www.den-ankyo.org/society/transition.html>（参照日 2019 年 11 月 22 日）。

深谷直樹, 多機能車椅子における路肩等段差昇降への対応, 日本交通科学学会誌, Vol.16, No.1 (2017), pp.36-45.

村上俊之, 高倉晋司, 大西公平, 外乱オブザーバによる障害物との衝突検知およびその回避モーション, 電気学会論 文誌D（産業応用部門誌），Vol.110, No.11 (1990), pp.1155-1162.

Nakajima, S., Development of a series of RT-Mover, which is a four-wheel type of mobile platform with an ability of negotiating obstacles, Journal of Robotics and Mechatronics, Vol.27, No.5 (2015), pp.587-589.

Nakao, M., Ohnishi, K. and Miyachi, K., A robust decentralize joint control based on interference estimation, Proceedings of the IEEE International Conference on Robotics and Automation (1987), pp.326-331. 
国土交通省鉄道局，鉄道駅におけるプラットホームと車両乗降口の段差・隙間に関する検討会，available form $<\mathrm{https}: / /$ www.mlit.go.jp/common/001304066.pdf $>$ （参照日 2020 年 8 月 1 日）.

国土交通省，標準仕様ノンステップバス，available form <https://www.mlit.go.jp/kisha/kisha04/09/090119/02.pdf > （参照日 2020 年 8 月 1 日）。

国土交通省，交通政策基本法の概要，available form <https://www.mlit.go.jp/common/001037350.pdf > (参照日 2019 年 12 月 3 日）。

森 善一, 勝村薰, 永瀬勝也, 自走用車椅子使用者のための段差移動補助機の開発, 日本機械学会論文集, Vol.80, No.820 (2014), DOI:10.1299/transjsme.2014dr0381.

宗方 宥，和田正義，5輪簡易電動車いすの段差昇降動作と操作支援シムテムの提案，ロボティクス・メカトロニ クス講演会 2016 講演論集 (2016), 2A1-01b4.

芝崎和男, 段差昇降式電動車椅子, 特開平 7-328073 (1995).

菅原雄介, 米澤直晃, 小菅一弘, 車輪付形状可変型 4 節リンク機構を用いた階段昇降機構, 日本ロボット学会誌, Vol.29, No.7 (2011), pp.599-608.

山崎惠子，山崎慎也，上本正護，車椅子の段差解消用昇降装置, 特開 2002-126010 (2002).

\section{References}

Arai, M., Genuinely useful accessibility information on transportation for wheelchair users, Social Design Review, Vol.10, No.1 (2019), pp.100-110 (in Japanese).

Association of Electric Wheelchair Safety Promotion, available from $<$ https://www.den-ankyo.org/society/transition.html>, (accessed on 22 November, 2019) (in Japanese).

Fukaya, N., Countermeasure for step of the road by using a mulchfunction wheelchair, Journal of the Japanese Council of Traffic Science, Vol.16, No.1 (2016), pp.33-45 (in Japanese).

Ministry of Land, Infrastructure, Transport and Tourism, Railway Bureau, available from $<$ https://www.mlit.go.jp/common/001304066.pdf>, (accessed on 1 August, 2020) (in Japanese).

Ministry of Land, Infrastructure, Transport and Tourism, available from $<$ https://www.mlit.go.jp/kisha/kisha04/09/090119/02.pdf >, (accessed on 1 August, 2020) (in Japanese).

Ministry of Land, Infrastructure, Transport and Tourism, available from $<$ https://www.mlit.go.jp/common/001037350.pdf >, (accessed on 3 December, 2019) (in Japanese).

Mori, Y., Katsumura, K. and Nagase, K., Development of a pair of step-climbing units for a manual wheelchair user, Transactions of the JSME (in Japanese), Vol.80, No.820 (2014), DOI:10.1299/transjsme.2014dr0381.

Munakata, Y. and Wada, M., Proposition of the step climbing/descending strategies and the control assist system for a fivewheeled wheelchair, Proceedings of the 2016 JSME Conference on Robotics and Mechatronics (2016), 2A1-01b4 (in Japanese).

Murakami, T., Takakura, S. and Ohnishi, K., Collision detection and recovery motion for industrial robot based on signal of disturbance obserber, The transactions of the Institute of Electrical Engineers of Japan. D, A publication of Industry Applications Society, Vol.110, No.11 (1990), pp.1155-1162 (in Japanese).

Nakajima, S., Development of a series of RT-Mover, which is a four-wheel type of mobile platform with an ability of negotiating obstacles, Journal of Robotics and Mechatronics, Vol.27, No.5 (2015), pp.587-589.

Nakao, M., Ohnishi, K. and Miyachi, K., A robust decentralize joint control based on interference estimation, Proceedings of the IEEE International Conference on Robotics and Automation (1987), pp.326-331.

Shibasaki, K., Step Ascending/descending electric wheelchair, Japanese Unexamined Patent Application Publication No.1995-328073 (1955) (in Japanese).

Sugahara, Y., Yonezawa, N. and Kosuge, K., A Stair-climbing wheelchair with wheeled transformable four-bar linkages, Journal of the Robotics Society of Japan, Vol.29, No.7 (2011), pp.599-608 (in Japanese).

Yamasaki, K., Yamasaki, S. and Uemoto, M., Elevator for level difference elimination for wheelchair, Japanese Unexamined Patent Application Publication No.2002-126010 (2002) (in Japanese). 